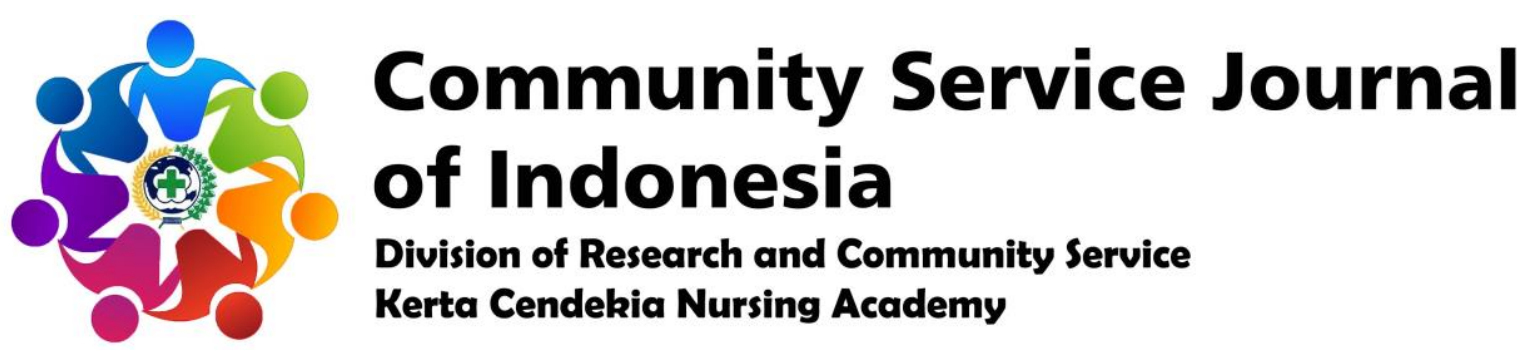

https://ejournal-kertacendekia.id/index.php/csji/index

Community Service Journal of Indonesia 1 (1) (2019): 11-13

Doi: https://doi.org/10.36720/csji.v1i1.67

\title{
HEALTHY LIFE AWARENESS IMPROVEMENT THROUGH HANDWASH HEALTH PROMOTION IN THE KINDERGARTEN OF SENTUL VILLAGE, TANGGULANGIN SUB-DISTRICT, SIDOARJO DISTRICT
}

\author{
Agus Sulistyowati ${ }^{1}$, Nur Azizah ${ }^{2}$, Belinda Anggraini Putri' ${ }^{2}$, Eno Desty Masrikat ${ }^{2}$, Lailis \\ Rizky Amalia², Mirza Safira², Yani Oksanti Putri², Indra Muhammad² \\ ${ }^{1}$ Lecturer of Kerta Cendekia Nursing Academy, Sidoarjo \\ ${ }^{2}$ Student of Kerta Cendekia Nursing Academy, Sidoarjo
}

\begin{abstract}
An increase in awareness of healthy living through health promotion in the Kindergarten of Sentul Village, Tanggulangin Sub-District, Sidoarjo District is a form of education in the form of counseling aimed at fostering and enhancing healthy behavior early, especially in recognizing good and proper hand washing procedures. The activity was held on November 27, 2018 at the Kindergarten of Sentul Village, Tanggulangin Sub-District, Sidoarjo District. The target is the students of the Kindergarten of Sentul Village, Tanggulangin Sub-District, Sidoarjo District. Before the implementation of these activities, there is a process of preparing activities for 3 weeks before the activities are carried out, starting from the selection of health counseling materials to the submission of permits to related parties. As an evaluation, the activity was attended by 41 students and 4 teachers, participants participated in the activity with enthusiasm and conduciveness, the activities could be carried out on time smoothly.
\end{abstract}

Keywords: Handwash health promotion, kindergarten, healthy life awareness.

\section{INTRODUCTION}

Hand washing is one of the acts of sanitation by cleaning hands and fingers using water or other means by humans in order to be clean, as part of religious rituals, or other purposes.
Hand washing behavior is different from hand washing behavior which refers to figurative words. Handwashing was only known at the end of the 19th century with the aim of being healthy when sanitation behavior and services were the cause of the sharp decline in mortality from infectious 
diseases found in rich (developed) countries. This behavior is introduced along with the isolation and enforcement of techniques for safe disposal of waste and adequate supply of clean water.

\section{OBJECTIVES}

General Purpose

After health promotion activity, the students of the Kindergarten of Sentul Village, Tanggulangin Sub-District, Sidoarjo District can understand the importance of hand washing, especially for body health.

\section{Special Purpose}

After taking health promotion measures, it is expected that the students of the Kindergarten of Sentul Village, Tanggulangin Sub-District, Sidoarjo District can:

1. Know the definition of hand washing.

2. Know the impact if you don't wash your hands.

3. Mention the signs and symptoms of syncope.

4. Demonstrate steps for hand washing.

\section{PLAN OF ACTION}

Strategy Plan

The strategy plan implemented, including:

1. Coordinate with the principal of the Kindergarten of Sentul Village, Tanggulangin Sub-District, Sidoarjo District to apply for permission to carry out health education or counseling as an activity of the nursing program and to help provide guidance to the students of the Kindergarten of Sentul Village, Tanggulangin Sub-District, Sidoarjo District.

2. Establish students in the implementation of health education or counseling to know about how to handle syncope cases.

3. Contract time with the students of the Kindergarten of Sentul Village, Tanggulangin Sub-District, Sidoarjo District.

4. Provide health promotion about how to handle syncope cases.

\section{Implementation}

Actions taken in the implementation of these activities, including:

1. Contacted the principal of the Kindergarten of Sentul Village, Tanggulangin Sub-District, Sidoarjo District to request permission for activities and gather the students of the Kindergarten of Sentul Village, Tanggulangin Sub-District, Sidoarjo District.

2. Prepare a place and counseling media.

3. The students of the Kindergarten of Sentul Village, Tanggulangin SubDistrict, Sidoarjo District received extension materials.

Setting

This activity was carried out at the Kindergarten of Sentul Village, Tanggulangin Sub-District, Sidoarjo District.

Target

Target in this activity is all of students at the Kindergarten of Sentul Village, Tanggulangin Sub-District, Sidoarjo District.

\section{RESULTS AND DISCUSSION}

The activity starts at $08.00 \mathrm{WIB}$ and ends at 09.30 , the time of health promotion according to planning. The activity was held at the Kindergarten of Sentul Village, Tanggulangin Sub-District, Sidoarjo 
District in accordance with the agreement. The participants were 41 students and 4 teachers. Participants seemed conducive and cooperative in the extension activities. Activities in the form of health counseling, discussion, question and answer, and distribution of leaflets about steps to wash hands. The equipment used during the discussion was laptops, power points, videos, and leaflets. The use of communicative and applicative language in the delivery of health education, students respond quite well to what has been conveyed by the presenter. The teachers of the Kindergarten of Sentul Village, Tanggulangin Sub-District, Sidoarjo District were very enthusiastic and worked together very well during the counseling. The participants who attended seemed enthusiastic to take part in counseling from the beginning to the end. Questions asked by participants can be answered well by presenters and teams. Based on the final evaluation, it was found that $75 \%$ of participants could mention the understanding of hand washing, $85 \%$ of participants could mention the impact if they did not wash their hands, $90 \%$ of participants could practice the steps to wash their hands, and $80 \%$ of participants could follow the counseling material well.

\section{CONCLUSION}

Healthy life awareness improvement through handwash health promotion in the kindergarten of Sentul Village, Tanggulangin Sub-District, Sidoarjo District was considered quite successful because $75 \%$ of participants could mention the understanding of hand washing, $85 \%$ of participants could mention the impact if they did not wash their hands, $90 \%$ of participants could practice the steps to wash their hands, and $80 \%$ of participants could follow the counseling material well..

\section{REFERENCES}

---, (2012). Pengertian mencuci tangan. Retrieved from http://fourseasonnews.blogspot.com/2 012/06/pengertian-mencucitangan.html on November 20, 2018.

Hendratno. (2007). Permasalahan umum kesehatan anak usia sekolah. Retrieved from http://anugerah.hendra.or.id/pascanikah/3-anak-anak/permasalahanumum-kesehatan-anak-usiasekolah/print/ on November 20, 2018

Nazwah, A. (2009). Satuan Acara Penyuluhan (SAP) Cara Mencuci Tangan Di Sekolah Dasar (SD). Retrieved from http://adelinecalonperawat.blogspot.c om/2009/03/sap-penyuluhan-cucitangan.html on November 20, 2018.

Notoatmodjo, S. (2007). Promosi kesehatan dan ilmu perilaku. Jakarta: Rineka Cipta. 